\title{
Hubungan Kekuatan Otot Lengan, Koordinasi Mata Tangan, Dan Rasa Percayadiri Dengan Keterampilan Smash Pada Permainan Bola Voli
}

\author{
1Heru Sulistiadinata, ${ }^{2}$ Tedi Purbangkara, \\ 1STKIP Pasundan, Cimahi, Jawa Barat, Indonesia \\ 2Universitas Singaperbangsa Karawang, Jawa Barat, Indonesia \\ ${ }^{1}$ sulistiadinata24@gmail.com, 22tedipurbangkara06@gmail.com
}

\begin{abstract}
ABSTRAK
Tujuan penelitian ini adalah untuk mengetahui (1) hubungan kekuatan otot lengan (X1) dengan keterampilan smash (Y), (2) hubungan koordinasi mata-tangan (X2) dengan keterampilan smash (Y), (3) hubungan rasa percaya diri (X3) dengan keterampilan smash (Y), (4) hubungan kekuatan otot lengan (X1) , rasa percaya diri (X3), koordinasi mata-tangan (X2), secara bersama-sama dengan keterampilan smash (Y). Metode yang digunakan adalah metode korelasi yang menggunakan perhitungan product moment. Sample berjumlah 39 orang seluruh siswa yang mengikuti ektrakulikuler bola voli. Instrumen penelitian yang digunakan adalah (1) kekuatan otot lengan dengan menggunakan push up, (2) koordinasi mata tangan dengan menggunakan instrument wall past test, (3) rasa percaya diri dengan menggunakan instrument kuesioner, (4) keterampilan smash dengan menggunakan test hasil total dari proses gerakan. Hasil pengujian hipotesis pertama terdapat hubungan yang positif antara kekuatan otot lengan (X1) dengan keterampilan smash (Y), kedua terdapat hubungan yang positif koordinasi matatangwan (X2) dengan keterampilan smash (Y), ketiga terdapat hubungan yang positif rasa percaya diri (X3) dengan keterampilan smash (Y), keempat terdapat hubungan yang positif kekuatan otot lengan (X1) , rasa percaya diri (X3), koordinasi mata-tangan (X2), secara bersama-sama dengan keterampilan smash (Y). Jadi dapat disimpulkan bahwa kekuatan otot lengan, koordinasi mata tangan, dan rasa percaya diri memiliki hubungan yang signifikan dengan keterampilan smash bola voli.
\end{abstract}

Kata Kunci: Otot Lengan, Koordinasi Mata-Tangan, Smash Bola Voli, dan Rasa Percaya Diri

\section{ABSTRAC}

The purpose of this study was to determine (1) the relationship of arm muscle strength (X1) with smash (Y) skills, (2) eye-hand coordination relationship (X2) with smash (Y) skills, (3) self-confidence relationship (X3) with smash (Y) skills, (4) relationship of arm muscle strength (X1), confidence (X3), eye-hand coordination (X2), together with smash (Y) skills. The method used is the correlation method that uses product moment calculations. There were 39 samples from all students who took volleyball extracurricular activities. The research instruments used were (1) arm muscle strength using push-up, (2) hand eye coordination using the wall past test instrument, (3) self-confidence using questionnaire instruments, (4) Smash skills using total test results from the movement process. The results of testing the first hypothesis there is a positive relationship between arm muscle strength (X1) with smash skills (Y), secondly there is a positive relationship between spy coordination (X2) and smash (Y) skills, thirdly there is a positive relationship of self-confidence (X3) with smash (Y) skills, fourth there is a positive relationship of arm muscle strength (X1), confidence (X3), eye-hand coordination (X2), together with smash (Y) skills. So it can be concluded that arm muscle strength, hand eye coordination, and self-confidence have a significant relationship with volleyball smash skills.

Keyword: Arm Muscle, Eye-Hand Coordination, Smash Volleyball and Self Confidence

Alamat Korespondensi: STKIP Pasundan

(C) 2020 STKIP Pasundan Email: sulistiadinata24@gmail.com

ISSN 2721-5660 (Cetak) 


\section{PENDAHULUAN}

Pelatihan olahraga bola voli pada hakikatnya merupakan suatu upaya pendidikan. Secara sederhana permainan bola voli bagi siswa atau atlet dapat diartikan sebagai proses belajar bergerak, atau belajar melalui gerak. Untuk terampil bermain bola voli pemain atau atlet harus memperagakan teknik atau taktik memainkan bola di lapangan untuk meraih kemenangan dalam setiap pertandingan. Teknik dasar memainkan bola voli yang harus di tingkatkan antara lain adalah service, passing, block dan smash. Salah satu tujuan bermain bola voli selain meningkatkan aktivitas fisik dan teknik adalah untuk meraih angka dan memenangkan pertandingan. Kemenangan dapat di raih dengan cara kerjasama tim yang baik. Dengan melakukan smash yang baik merupakan sebuah serangan yang baik pula.

Smash merupakan gerakan yang esensial, cara yang mudah untuk memenangkan angka (Dieter, 2012). "The smash is the principal attack shot used in volleyball" (Royal, 2005). Sehinga dapat di simpulkan bahwa Smash adalah serangan yang dilakukan terhadap pihak lawan.Tindakan ini dilakukan ketika bola sedang melambung diatas net baik yang dihasilkan dari umpan atau passing teman sepermainan atau bola yang berasal dari arah lawan yang dimanfaatkan untuk melakukan pukulan keras. Dilihat dari pengertiannya, smash dapat di definisikan sebuah cara memainkan bola secara efektif dan efisien untuk mendapatkan hasil optimal, tapi tetap perpegang pada peraturan permainan yang telah ditetapkan.

Pada pertandingan olahraga, terutama pada saat pertandingan bola voli, penggunaan skill yang dimiliki serta penggunan tektik dan siasat terkadang lebih rendah dibandingkan penggunaan emosi tinggi. Penggunaan teknik menjadi tidak terarah dan pertandingan menjadi emosional. Hal ini tidak kondusif bagi pertandingan yang sportif dan menarik. Kekompakan team akan melemah karena ada kesenjangan harapan dan kenyataan. Koordinasi dan kerjasama timakan mempengaruhi hasil akhir dari pertandingan terutama pada pertandingan beregu. Secara psikologis kondisi mental akan berpengaruh terhadap prilaku atlet dan kekompakan tim di lapangan.

Kecepatan dan arah bola bola hasil dari smash yang sempurna ke area lawan akan sulit untuk diprediksi oleh pemain bertahan. Memainkan bola smash tidaklah mudah dalam situasi dan kondisi saat pertandingan. Kondisi ini merupakan sebuah kesempatan yang dapat di manfaatkan secara maksimal oleh seorang yang melakukan smash atau tim lawan untuk menghasilkan angka. Pada saat melakukan smash bisa berarti positif atau negatif tergantung dari kemampuan atlet tersebut dalam melakukan smash dengan baik dan ketepatan waktu penerimaan bola serta posisi pada saat menerima bola.

Permasalahan yang tidak di teliti akan menimbulkan kerugian, terutama terkait dengan kemampuan teknik pengumpan yang tepat dan smash. Pemahaman tentang smash dan apekaspek yang terkait secara teknis dan taktis akan memberikan gambaran jelas mengenai ketetapan 
umpan yang tepat yang dapat di terapkan dalam permainan bola voli. Tanpa ketinggian umpan yang tepat seorang smashr akan mengalami kesulitan dalam melakukan smash yang efektif.

Dalam olahraga bola voli juga memerlukan fostur tubuh dan kondisi fisik yang prima, dalam arti kata bermain bola voli selain daripada teknik juga fisik yang yang baik, dalam hal ini peneliti mengambil kekuatan otot lengan sebagai bahan penelitian karena olahraga bola voli juga dominan menggunakan otot lengan, dalam hal ini berfungsi sebagai organ untuk memukul atau memberi umpan pada pemain dan olahraga bola voli juga sudah seharusnya menggunakan koordinasi mata dan tangan dengan baik sehingga penempatan bola bisa tepat sasaran.

Menurut Honeybourne (2006) "The word skilful is used to describe the motor movements of someone who has achieved excellence in their activity". William (2011) menyatakan "A skill domain is the grouping of skills based upon the underlying capacities most essential for accomplishing them". Semakin tinggi kemampuan seseorang mencapai tujuan yang diharapkan, maka semakin terampil orang tersebut.

Keterampilan merupakan kemampuan untuk membuat hasil akhir dengan kepastian yang maksimum, tetapi dengan pengeluaran energi dan waktu yang minimum (Mahendra, 2007). "the ability to bring about some end result with maximum certainty and minimum outlay of energy, or of time and energy" (Schmidt \& Lee, 2014). Dari berbagai pendapat ahli diatas dapat di simpulkan bahwa keterampilan adalah pelaksanaan yang cepat dalam arti penyelesaian tugas yang minimum.

Banyak gerak yang menggunakan tangan dipertimbangkan sebagai gerak halus. Keterampilan ini melibatkan koordinasi neuromuskuler yang memerlukan ketepatan derajat tinggi untuk berhasilnya keterampilan ini. "The F-S (strength-speed) axis refers mainly to sports in which power is dominant" (Bompa \& Buzzichelli, 2015). Pencapaian suatu keterampilan dipengaruhi oleh banyak faktor yang secara umum dibedakan menjadi tiga hal yang utama, yaitu (1) faktor proses belajar mengajar, (2) faktor pribadi, dan (3) faktor situasional (Ma'mun \& Saputra, 2000).

Ada tiga hal yang dapat diidentifikasi dalam tahap belajar keterampilan gerak, yaitu tahapan verbal-kognitif, tahapan motorik, dan tahapan otomatisasi (Ma'mun \& Saputra, 2000), dan menurut Widiastuti (2011) ada tiga hal yang dapat diidentifikasi dalam tahap belajar keterampilan, yaitu 1) Keterampilan adaptif sederhana, 2) keterampilan adaftif terpadu, dan 3) keterampilan adaptif kompleks. Ketiga tahap belajar di atas diuraikan sebagai berikut: tahap kognitif, tahap motorik, tahap otomatisasi.

Untuk melakukan suatu kegiatan olahraga seseorang membutuhkan kondisi fisik yang baik, kondisi fisik merupakan suatu kesatuan yang tidak dapat di abaikan dalam mencapai kemampuan maksimal. "The human body is structured in such a way that it maintains relatively stable internal physiological conditions, or homeostasis" (Gregory, 2006). Dalam permainan bola 
voli teknik smash adalah merupakan faktor yang sangat penting yang harus dimiliki oleh seorang pemain bola voli. Teknik smash yang dicapai setelah melakukan gerakan smash sangat dipengaruhi oleh kekuatan. Kekuatan merupakan unsur penting dalam tubuh manusia, kekuatan adalah komponen yang sangat penting guna meningkatakn kondisi fisik seseorang secara keseluruhan.

Kekuatan adalah kemampuan untuk melawan tahanan/resistan atau beban fisik baik dari luar maupun dari badannya sendiri, kekuatan dibagi menjadi yaitu : (1) Kekuatan Maksimal. (2) Kekuatan Elastis, (3) Daya Tahan Kekuatan (James, 2012). Hidayat (2003) menjelakan dalam bukunya bahwa "kekuatan adalah gaya yang ditimbulkan oleh kontraksi otot". The concept of power is useful in biomechanics for several reasons. the bast way to explain one use of power is by example. suppose you have to move a stack finish this task of book one from one table to another, and you want to finish this task as quickly as possible" This is mean that you want to maximize your power output (Peter, 2005). Dan secara sederhana kekuatan dapat diartikan sebagai kemampuan untuk memberikan tenaga terhadap tekanan dalam melakukan smash dalam permainan bola voli. Peneliti juga menemukan pendapat lain tentang kekuatan diantaranya sebagai berikut "kekuatan adalah gaya maksimal atau torque (gaya rotasi) yang dapat dihasilkan oleh sebuah atau sekolompok otot (Johansyah, 2013).

Keterampilan smash adalah gerakan perpaduan fungsi otot secara tepat dan seimbang menjadi pola gerak. Setiap pemain bola voli harus menguasai teknik dasar smash dengan baik untuk mendukung penampilan keterampilannya pada saat bermain bola voli. Koordinasi matatangan penting dalam menunjang keterampilan teknik-teknik dalam permainan bola voli. Koordinasi mata-tangan adalah kemampuan sistem visi untuk mengkoordinasikan informasi yang diterima melalui mata untuk mengendalikan, membimbing, dan mengarahkan tangan dalam pemenuhan tugas yang diberikan, dalam hal ini smash. Koordinasi mata-tangan menggunakan mata untuk perhatian langsung dan tangan untuk melakukan smash. Dengan demikian tingkat koordinasi seorang pemain akan berhubungan dengan baik buruknya smash yang dihasilkan. Dengan koordinasi mata-tangan yang baik maka pemain akan melakukan smash dengan baik pula.

Percaya Diri (Self Confidence) adalah meyakinkan pada kemampuan dan penilaian (Judgement) diri sendiri dalam melakukan tugas dan memilih pendekatan yang efektif (Monty, 2000). Kepercayaan diri berisi keyakinan yang terkait dengan kekuatan, kemampuan diri untuk melakukan dan meraih sukses, serta bertanggung jawab terhadap apa yang telah di tetapkan oleh dirinya. Penampilan terbaik adalah korelasi langsung antara kepercayaan diri yang tinggi dan keberhasilan performa olahraga (Komarudin, 2015). Hal ini termasuk kepercayaan atas kemampuannya menghadapi lingkungan yang semakin menantang dan kepercayaan atas keputusan atau pendapatnya. 
Berdasarkan itu semua, kita juga bisa membuat semacam kesimpulan bahwa kepercayaan diri itu adalah efek dari bagaimana kita merasa, meyakini, dan mengetahui. Orang yang punya kepercayaan diri rendah atau kehilangan kepercayaan diri memiliki perasaan negatif terhadap dirinya, memiliki keyakinan lemah terhadap kemampuan dirinya dan punya pengetahuan yang kurang akurat terhadap kapasitas yang dimilikinya.

\section{METODE}

Metode penelitian yang digunakan dalam penelitian ini adalah survey dengan rancangan korelasional. Penelitian survay bersifat non eksperimen. Pada penelitian ini peneliti menggunakan tiga variabel bebas dan satu variabel terikat. Adapun variabelnya adalah kekuatan otot lengan $\left(\mathrm{X}_{1}\right)$, koordinasi mata tangan $\left(\mathrm{X}_{2}\right)$, rasa percaya diri $\left(\mathrm{X}_{3}\right)$ selaku variabel bebas, sedangkan untuk variabel terikat peneliti menggunakan keterampilan smash (Y). Keempat pola hubungan variabel tersebut merupakan kontelasi dalam penelitian ini. Pola hubungan antara variabel penelitian terlihat pada gambar berikut:

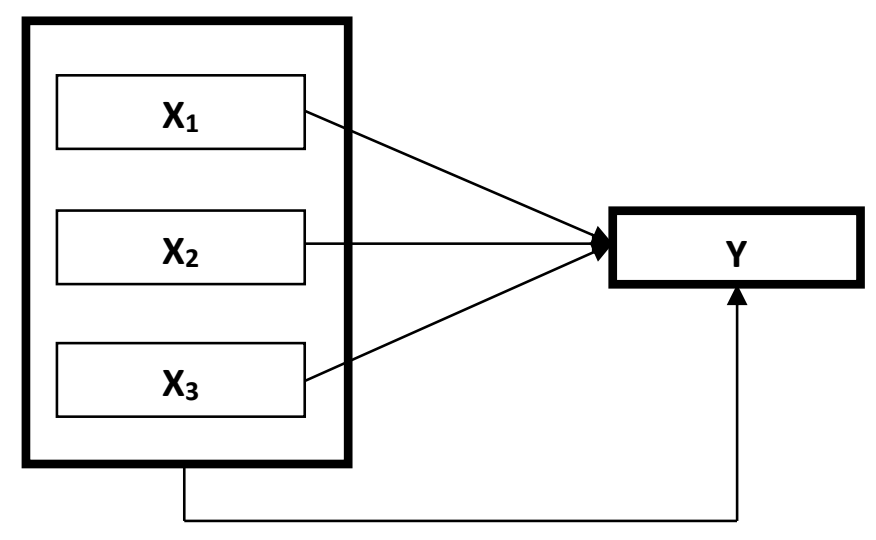

Gambar 2.1

Korelasi hubungan antara $X_{1}, X_{2}, X_{3}$ dengan $Y$

Keterangan:

Y : Smash

X1 : Kekuatan Otot Lengan

X2 : Koordinasi mata-tangan

X3 : Tingkat Percaya diri

Untuk teknik analisis data yang digunakan dalam penelitian adalah teknik regresi dan korelasi. Sebelum dilakukan penghitungan, maka semua data yang masuk dari empat variabel penelitian di ubah terlebih dahulu menjadi data yang sudah di T-scorekan. Hal ini dilakukan selain untuk menyamakan satuan dari empat variabel yang berbeda, juga untuk menyelaraskan agar 
semua skor dari empat variabel yang ada, tidak mempunyai rentang yang cukup mencolok. Langkah-langkah yang dilakukan untuk pengolahan data menggunakan SPSS 19.0 for windows, dengan persyaratan analisis yang digunakan dalam penelitian ini adalah pengujian normalitas (Liliefors), Uji Linearitas, Uji Signifikasi Liniear, Regresi dan Korelasi.

\section{HASIL DAN PEMBAHASAN \\ Hasil}

Tabel 1

$F_{\text {hitung Variabel Kekuatan Otot Lengan }}\left(\mathrm{X}_{1}\right)$, Koordinasi Mata-Tangan $\left(\mathrm{X}_{2}\right)$ dan Rasa Percaya Diri $\left(\mathrm{X}_{3}\right)$ terhadap Variabel Hasil Keterampilan Smash (Y)

\begin{tabular}{|rl|r|r|r|r|r|}
\hline \multicolumn{1}{|l|}{ Model } & & Sum of Squares & Df & Mean Square & F & \multicolumn{1}{c|}{ Sig. } \\
\hline 1 & Regression & 555.646 & 3 & 118.549 & 22.167 & $.918^{\mathrm{a}}$ \\
& Residual & 3885.123 & 35 & 111.004 & & \\
Total & 3940.769 & 38 & & & \\
\hline
\end{tabular}

Uji F dilakukan untuk menguji hipotesis ini adalah :

1) $\mathrm{H}_{0}=0$; atau model regresi tidak signifikan

2) $\mathrm{H}_{1} \neq 0$; atau model regresi signifikan

Dasar dari pengambilan keputusan adalah :

1) Jika $F_{\text {hitung }} \leq \mathrm{F}_{\text {tabel }}$ maka $\mathrm{H}_{1}$ ditolak, $\mathrm{H}_{0}$ diterima

2) Jika $F_{\text {hitung }}>F_{\text {tabel }}$ maka $H_{1}$ diterima, $\mathrm{H}_{0}$ ditolak

Dengan bantuan pengolahan komputer berdasarkan perhitungan SPSS 19.0 for windows tersebut di peroleh Fhitung sebesar 22.167 sedangkan harga kritis nilai $\mathrm{F}_{\text {tabel }}$ dengan derajat bebas pembilang 1 dan penyebut 38 pada $\alpha(0.05)$ sebesar 2,866.

Dengan demikian $\mathrm{F}_{\text {hitung }}(22,167)>\mathrm{F}_{\text {tabel }}(2,866)$, sehingga jelas $\mathrm{H}_{0}$ ditolak dan $\mathrm{H}_{1}$ diterima. Hal ini menunjukan bahwa model regresi variabel kekuatan otot lengan signifikan dengan variabel hasil keterampilan smash.

\section{KESIMPULAN}

- Terdapat hubungan yang positif antara kekuatan otot lengan (X1) dengan hasil keterampilan smash bola voli (Y). Hal ini berarti bahwa semakin baik tingkat kekuatan otot lengan maka semakin baik pula kekuatan smash bola voli. Sebaliknya, semakin rendah kekuatan otot lengan maka semakin rendah pula kekuatan dalam melakukan smash bola voli

- Terdapat hubungan yang positif antara koordinasi mata-tangan (X2) dengan hasil keterampilan smash bola voli (Y). ). Hal ini berarti bahwa semakin baik tingkat koordinasi mata tangan maka semakin baik pula kekuatan smash bola voli. Sebaliknya, semakin rendah 
koordinasi mata-tangan maka semakin rendah pula koordinasinya dalam melakukan smash bola voli

- Terdapat hubungan yang positif antara rasa percaya diri (X3) dengan hasil keterampilan smash bola voli (Y). Hal ini berarti bahwa semakin baik tingkat rasa percaya diri maka semakin baik pula kekuatan smash bola voli. Sebaliknya, semakin rendah kekuatan otot lengan maka semakin rendah pula rasa percaya diri dalam melakukan smash bola voli

- Terdapt hubungan yang positif secara bersama-sama antara kekuatan otot lengan (X1) koordinasi mata tangan (X2) dan rasa percaya diri (X3) secara bersama-sama terhadap hasil keterampilan smash bola voli (Y). Hal ini berarti bahwa makin baik tingkat kekuatan otot lengan, koordinasi mata tangan, dan rasa percaya diri secara bersama-sama merupaka salah satu variabel yang sangat terkait dengan kemampuan samsh bola voli.

\section{DAFTAR PUSTAKA}

Bompa, T. O. \& Buzzichelli, C. (2015). Priodization Training For Sport. Canada : Human Kinetis.

Dieter, B. (2012). Belajar Bermain Bola voli. Bandung : CV. Pionir Jaya.

Gregory, W. (2006). The Phisiology Of Training. British Library : Churehill Livingstone Elsevier.

Hidayat, R.I. 2003) Biomekanika. Bandung : PPS Universitas Pendidikan Indonesia.

Honeybourne, J. (2006). Acquiring Skill In Sport. New York: The Taylor \& Francie e-Library.

James, T. (2012) Kepelatihan Olahraga "Pembinaan Prestasi Olahraga".Jakarta : Cerdas Jaya.

Johansyah, L. (2013). Panduan Praktis Penyusunan Program Latihan. Jakarta : PT. Raja Grapindo.

Komarudin. (2015). Psikologi Olahraga. Bandunng : PT. Remaja Rosdakarya Offset.

Mahendra, A. (2007). Modul Teori Belajar Mengajar Motorik. Bandung : FPOK - UPI.

Ma'mun, Amung \& Saputra, Yudha Munajat. (2000). Perkembangan Gerak dan Belajar Gerak. Jakarta: Departemen Pendidikan dan Kebudayaan.

Monty, P.S. (2000). Dasar-dasar Psikologi Olahraga. Jakarta : Pustaka Sinar Harapan.

Peter, M. (2005). Biomechines Of Sport And Exercise. New Zealand : Human Kinetis.

Royal, N. (2005). Volley Ball. London : The Royal Marines.

Schmidt, R.A., \& Lee, T.D. (2014). Motor Learning And Performance From Principles To Application. United States : Human Kinaetis

Widiastuti. (2011). Tes dan Pengukuran Olahraga. Jakarta : PT. Bumi Timur Jaya.

William, E. (2011). Motor Learning And Motor Control. Wandsworth : Cangage Learning. 